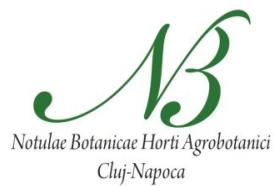

\title{
Determination of Major-to-Trace Minerals and Polyphenols in Different Apple Cultivars
}

\author{
Doina TODEA ${ }^{1}$, Oana CADAR ${ }^{2 *}$, Dorina SIMEDRU², Cecilia ROMAN², \\ Claudiu TANASELIA ${ }^{2}$, Iuliu SUATEAN ${ }^{3}$, Anca NAGHIU ${ }^{2}$
}

\author{
1"Iuliu Hatieganu"University of Medicine and Pharmacy, Faculty of Medicine, Pneumology Department, Cluj-Napoca, Romania; dtodea@umfcluj.ro \\ ${ }^{2} I N C D O-I N O E$ 2000, Research Institute for Analytical Instrumentation, 67 Donath, \\ 400293 Cluj-Napoca, Romania; oana.cadar@icia.ro ("correspondingauthor) \\ 3University of Agricultural Sciences and Veterinary Medicine, 3-5 Manastur, 400372 Cluj-Napoca, Romania; isuateani@yahoo.com
}

\begin{abstract}
The aim of this study was to investigate the concentration level of some major-to-trace elements and toxic minerals and polyphenols (catechin, epicatechin and quercetin) in fruits belonging to different apple cultivars ('Auriu de Cluj', 'Florina', 'Generos', 'Golden Delicious', 'Prima', 'Productiv de Cluj' and 'Starkrimson'), under specific climate conditions to northwestern Romania. The apple minerals were determined by the inductively coupled plasma mass spectrometry (ICP-MS) and inductively coupled plasma optical emission spectrometry (ICP-OES) after a preliminary, microwave-assisted, acid digestion. The polyphenols were determined by high performance liquid chromatography (HPLC) with MS/MS detection. According to the obtained results, the edible part of the apple contains many minerals with high relative nutritional value (RNV). The major minerals (Na, K, Ca, Mg and P), minor elements ( $\mathrm{Cu}, \mathrm{Fe}, \mathrm{Mn}, \mathrm{Sr}$ and $\mathrm{Zn}$ ) and toxic trace elements (Cd, $\mathrm{Cr}$ and $\mathrm{Pb}$ ) were comparatively identified and quantified. It was found that $\mathrm{K}(31976 \mathrm{mg} / \mathrm{kg})$ was predominant among the major elements, while $\mathrm{Fe}(3.68 \mathrm{mg} / \mathrm{kg})$ and $\mathrm{Cu}(3.57 \mathrm{mg} / \mathrm{kg})$ were comparable. The toxic trace metals $(\mathrm{Cd}, \mathrm{Cr}$ and $\mathrm{Pb})$ were below the limits of detection $(0.01,0.10$ and $0.01 \mathrm{mg} / \mathrm{kg}$, respectively) and did not determine any health risk to consumers. The main polyphenols composition (catechin, epicathechin, quercetin) differs slightly among different cultivars. In 'Idared' and 'Jonathan' cultivars, the investigated polyphenols are in higher quantities comparing to the others. In all investigated apple cultivars, quercetin was proved to be the major polyphenol, followed by epicathechin and catechin. These results suggest that, regarding only the investigated polyphenols, 'Idared' and 'Jonathan' cultivars have the highest antioxidant character in all investigated genotypes.
\end{abstract}

Keywords: apple fruits, multi-elements, polyphenols

\section{Introduction}

Apples are the second most produced tree fruits (apple crop is estimated at 69 million metric tonnes/year) in the world, after bananas (FAO, 2011). Apples represent an important part of the human diet because they are a good source of fiber, including the soluble fiber pectin, Vitamin A, Vitamin C, minerals and polyphenols (Wu et al., 2007). Besides 75-95\% water, the edible portion of apple contains an important quantity of phenolic compounds, which contribute to the flavor and can protect the human body from free radicals and reactive oxygen species (Cindrić et al., 2012; Hyson, 2011; Pandey et al., 2009).

Numerous studies on apples have been carried due to their nutritional importance, mainly regarding their acid, amino acid, mineral, vitamin and polyphenol contents (Auclair et al., 2008; Vieira et al., 2009; Ko et al., 2005). Approximately 30 elements are considered essential to life.
Essential nutrients which are needed in trace and ultratrace quantities $(\mathrm{Cu}, \mathrm{Fe}, \mathrm{Ni}, \mathrm{Zn}, \mathrm{Mn}, \mathrm{Co}, \mathrm{Cr}$, and $\mathrm{Se})$, are as important for life as macronutrients $(\mathrm{Ca}, \mathrm{K}, \mathrm{Mg}$ and $\mathrm{Na}$ ) (Cindric et al., 2011). However, some essential elements may become toxic when their concentration increases. The polyphenol family (phenolic acids, stilbenes, chalcones, coumarins, cromones, lignans, flavonoids, isoflavonoids, neoflavonoids and tannins) has been shown to possess significant antioxidant capacities, while they are maintaining low toxicities (Escudero et al., 2008). Apple polyphenols have been registered among Japanese Standard Food Additives as antioxidants due to their strong antioxidant activity (Enomoto et al., 2006). Between the apple polyphenols, flavonoids such as epicatechin, catechin and quercetin (Tab. 1) are the most important being widely distributed in natural products and medicinal herbs (Chang and $\mathrm{Wu}, 2011)$. Catechin and epicatechin have antioxidant, 
Tab. 1. Basic information of selected polyphenols

\begin{tabular}{|c|c|c|c|}
\hline Chemical name & Chemical class & Structural formula & Molecular weight $(\mathrm{g} / \mathrm{mol})$ \\
\hline Catechin & Flavan-3-ol & & 290.27 \\
\hline Epicatechin & Flavan-3-ol & & 290.27 \\
\hline Quercetin & Flavonol & & 302.23 \\
\hline
\end{tabular}

anticancer, antiangiogenic, antimutagenic, antibacterial, anti-HIV and anti-inflammatory effects (Chang and $\mathrm{Wu}, 2011$ ). Quercetin exhibits a variety of biological activities, including cardiovascular protection and anticancer, anti-inflammatory and antioxidant activities (Wang et al., 2005).

In order to obtain good quality data, several aspects such as: sample preparation, techniques used to identify the targeted compounds and the variables which influence the quality of the apple, must be considered.

Sample preparation is an important step in elemental analysis. Microwave-assisted digestion is characterized by short digestion time, small volume of reagent consumption, lower losses of volatile metals, good recoveries, accuracy, reproductibility and enhanced operator safety (Krushevska et al., 1993; Lamble et al., 1998; Bocca et al., 2007). ICPAES is a rapid and accurate technique for the simultaneous determination of the minor and major element contents in apples and apple juices as well. ICP-MS technique has become to be considered as the most powerful analytical tool for simultaneous trace elemental analysis of food samples due to its extreme sensitivity, selectivity and last but not the least due to its multielemental and isotopic capability (Barnes, 1999; Davidowski et al., 2009; Froes et al., 2009; Zeiner et al., 2010; Cindrić et al., 2012).

Liquid chromatography tandem mass spectrometry (LC/MS/MS) in the multiple reaction monitoring (MRM) mode has been recognized as a powerful analytical tool due to its high sensitivity and short run time (Hossain et al., 2010). Through this technique, less toxic organic solvents are used as mobile phase and is the most free of interferences compared to other chromatographic techniques (Hossain et al., 2010; Weingerl et al., 2009).

The chemical composition of the apples is a good indicator of their quality, consumer acceptability and the health status of consumers. There are many factors that influence the chemical composition and the nutritional value of apples, such as: apple variety, soil quality, production area, farming practices, the quality of irrigation water, local climate conditions, storage and commercialization conditions. In order to avoid the influence of these factors, the samples were collected from only one farm, during one harvest/year and not representative for the market. In Central Transylvania, Romania, the most famous and the most consumed apple cultivars were: 'Golden Delicious', 'Gustav', 'Jonathan', 'Kaltherer', 'Starkrimsom'. These old apple cultivars have become well adapted to the soil and climate conditions producing good yields and high-quality fruits. The renewal process of apple variety seems to be slow and difficult both due to high costs of a new apple orchard and the attitude of farmers/consumers. The most well-known and spreaded cultivars of apples created at Fruit Research Station ClujNapoca were 'Aromat de vara', 'Ardelean', 'Ancuta', 'Feleac", 'Rosu de Cluj', 'Auriu de Cluj', 'Estival' and 'Productiv de Cluj' (Sestras et al., 2006; Militaru et al., 2013).

The aim of this study was to determine the content of macro- ( $\mathrm{Na}, \mathrm{K}, \mathrm{Ca}, \mathrm{Mg}$ and $\mathrm{P})$, micro- $(\mathrm{Cu}, \mathrm{Fe}, \mathrm{Mn}, \mathrm{Sr}$ and $\mathrm{Zn})$ and toxic trace elements $(\mathrm{Cd}, \mathrm{Cr}$ and $\mathrm{Pb}$ ) and polyphenols (catechin, epicatechin and quercetin) of ten cultivars of apple fruits, under the climate conditions of Cluj-Napoca area, Romania.

\section{Materials and methods}

\section{Sampling}

The fruit samples, 10 cultivars of apple ('Auriu de Cluj', 'Florina', 'Generos,' 'Golden Delicious', 'Idared', 'Jonagold', 'Jonathan', 'Prima', 'Productiv de Cluj' and 'Starkrimson'), were collected from a private orchard, located near ClujNapoca, during September 2012 and 2013. Cluj-Napoca, being located in the northwestern part of Romania, has a continental climate, characterized by warm, dry summers and cold winters.

\section{Reagents and CRMs}

All reagents used for this research, were of p.a. grade and purchase from Merck, Darmstadt $\left(\mathrm{H}_{2} \mathrm{O}_{2} 30 \%\right.$, $\mathrm{HNO}_{3} 65 \%$, ICP Multielement standard IV). The certified reference material (NIST-SRM 1515 apple leaves) was obtained from 
525

LGC Standards GmbH, Wessel, Germany. Catechin, epicatechin and quercetin were purchased from AppliChem (USA). Methanol LC-MS Optigrade ( $\geq 99.8 \%$ ), Ethanol LCMS Optigrade ( $\geq 99.8 \%)$ and Ortophosphoric acid ULC-MS Optigrade (99-100\%) were acquired from LGC Standards. All glassware was cleaned with nitric acid prior to use. For all dilutions ultrapure water $(18.2 \mathrm{M} \Omega / \mathrm{cm})$ obtained from a Millipore Direct-Q3 UV system (Millipore, Molsheim, France) was used.

\section{Sample preparation}

Fruits were picked at harvest maturity as it is recommended for fruits that are marked out for storage. Fruit samples consisted of five individual apple fruits picked from the same tree of the investigated orchard. The fruit samples were washed first, several times with deionized water to remove the dust particles and then dried at $105^{\circ} \mathrm{C}$ for $24 \mathrm{~h}$ and homogenized. The dried samples were grounded, homogenized using a metalfree mortar and stored in polyethylene bags until acid digestion.

Per sample, $0.5 \mathrm{~g}$ was weighted accurately in a dry, clean PTFE vessel; $6 \mathrm{~mL}$ of $\mathrm{HNO}_{3} 65 \%$ and $3 \mathrm{~mL}$ of $\mathrm{H}_{2} \mathrm{O}_{2} 30 \%$ were added to each sample and the vessel content was kept $4 \mathrm{~h}$ at room temperature before digestion. After this, the samples were digested using a four-step digestion program (time [ $\mathrm{min}] /$ power $[\mathrm{W}] / / \mathrm{T}\left[{ }^{\circ} \mathrm{C}\right]: \quad 10 / 700 / 170 ; 15 / 1000 / 200$; $10 / 1000 / 160 ; 10 / 1000 / 100 ; 10 \mathrm{~min}$ ventilation). After mineralization, clear solutions were cooled at room temperature, and then quantitatively transferred to $25 \mathrm{~mL}$ volumetric flasks and diluted to the mark with deionized water. Certified reference material NIST-SRM 1515 apple leaves and blank, consisting of deionized water and reagents, were prepared in the same way as the samples. Three replicate measurements were made for each sample.

In order to determine the polyphenol content, the edible portion of the fruit was sliced into small pieces with a ceramic knife and lyophilized to avoid the degradation of the samples. $100 \mathrm{~g}$ of each dried vegetable product were extracted for 5 hours with $\mathrm{EtOH}: \mathrm{H}_{2} \mathrm{O}(90 / 10$, v/v) using a Soxhlet. The extract was dried under constant flow of compressed nitrogen gas, and reconstituted in mobile phase before injection. The recovery degree for all three polyphenols was situated in 77 $94 \%$ range and was measured using internal standard addition.

\section{Instrumentation}

For the microwave digestion of samples, a closed vessel microwave system Berghof MWS-3+ (Eningen, Germany) was used. The contents of $\mathrm{Ca}, \mathrm{Mg}, \mathrm{Na}, \mathrm{K}, \mathrm{Fe}$ and $\mathrm{P}$ were determined by ICP-OES (OPTIMA 5300 DV, Perkin Elmer, Norwalk, USA), while those of $\mathrm{Cd}, \mathrm{Cu}, \mathrm{Mn}, \mathrm{Pb}, \mathrm{Sr}$ and $\mathrm{Zn}$ by ICP-MS (ELAN DRC II, SCIEX, Perkin Elmer, Toronto, Canada). The calibration standards were prepared by diluting the stock multi-elemental standard solution $(1000 \mathrm{mg} / \mathrm{L})$ in $2 \% \mathrm{HNO}_{3}$ and the calibration ranges were modified according to the expected concentration values of investigated elements.

The LC/MS/MS analysis were carried out by a HPLC Agilent 1200 Series coupled with an Applied Biosystems API 3200 QTRAP mass spectrometer. The LC (liquid cromatograph) parameters are: Injection volume: 50 ul; Flow rate: $500 \mu \mathrm{l} / \mathrm{min}$; Chromatographic column: Synergi Hydro RP $150 \times 4.6 \mathrm{~mm}, 4 \mu \mathrm{m}$, Phenomenex, Torrance, California, USA; Column temperature: $33{ }^{\circ} \mathrm{C}$; Mobile phase: A: $\mathrm{H}_{2} \mathrm{O}+0.1 \%$ ortophosphoric acid; $\mathrm{B}: \mathrm{MeOH} ;$ Gradient program (Tab. 2). The MS/MS parameters are presented in Tab.3.

Tab. 2. Gradient flow for LC column separation of catechin, epicatechin and quercetin

\begin{tabular}{cccc}
\hline $\begin{array}{c}\text { Total time } \\
(\mathrm{min})\end{array}$ & $\begin{array}{c}\text { Flow rate } \\
(\mu \mathrm{l} / \mathrm{min})\end{array}$ & $\mathrm{A}(\%)$ & $\mathrm{B}(\%)$ \\
\hline 0.00 & 500 & 90.0 & 10.0 \\
25.00 & 500 & 10.0 & 90.0 \\
\hline
\end{tabular}

Tab. 3. Detection parameters (compound and source dependent) for catechin, epicatechin and quercetin

\begin{tabular}{lcccccc}
\hline Compound & $\begin{array}{c}\text { Q1 } \\
\text { Mass } \\
(\mathrm{u})\end{array}$ & $\begin{array}{c}\text { Q3 } \\
(\mathrm{u})\end{array}$ & $\begin{array}{c}\text { DP } \\
(\mathrm{V})\end{array}$ & $\begin{array}{c}\text { EP } \\
(\mathrm{V})\end{array}$ & $\begin{array}{c}\text { CE } \\
(\mathrm{V})\end{array}$ & $\begin{array}{c}\text { CXP } \\
(\mathrm{V})\end{array}$ \\
\hline Catechin & 288,8 & 190,9 & -45 & -5 & -10 & -4 \\
\hline Epicatechin & 288,9 & 244,9 & -40 & -7.5 & -22 & 0 \\
Quercetin & 300,9 & 150,8 & -45 & -5.5 & -30 & -2
\end{tabular}

FIA parameters

CUR:10.00 psi; CAD:Medium; IS:-4500.00V; TEM:600 ${ }^{\circ} \mathrm{C}$; GS1:35 psi; GS2:20 psi.

Tab. 4. Analysis of certified reference material (NIST-SRM 1515-Apple Leaves)

\begin{tabular}{cccc}
\hline Element & $\begin{array}{c}\text { Certified value }^{\mathrm{a}} \\
(\mu \mathrm{g} / \mathrm{g})\end{array}$ & $\begin{array}{c}\text { Obtained value } \\
(\mu \mathrm{g} / \mathrm{g})\end{array}$ & $\begin{array}{c}\text { Recovery } \\
(\%)\end{array}$ \\
\hline $\mathrm{Cd}$ & $0.013 \pm 0.002$ & $0.012 \pm 0.002$ & 92.3 \\
$\mathrm{Cu}$ & $5.64 \pm 0.24$ & $5.41 \pm 0.07$ & 95.9 \\
$\mathrm{Fe}$ & $83.0 \pm 5.0$ & $81.5 \pm 1.1$ & 98.2 \\
$\mathrm{Mn}$ & $54.0 \pm 3.0$ & $49.2 \pm 1.0$ & 91.0 \\
$\mathrm{~Pb}$ & $0.470 \pm 0.024$ & $0.442 \pm 0.024$ & 94.0 \\
$\mathrm{Zn}$ & $12.5 \pm 0.3$ & $10.9 \pm 1.0$ & 87.2 \\
$\mathrm{Ca}(\%)$ & $1.526 \pm 0.015$ & $1.432 \pm 0.102$ & 93.8 \\
$\mathrm{~K}(\%)$ & $1.61 \pm 0.02$ & $1.42 \pm 0.07$ & 88.2 \\
$\mathrm{Mg}(\%)$ & $0.271 \pm 0.008$ & $0.272 \pm 0.081$ & 101 \\
\hline
\end{tabular}

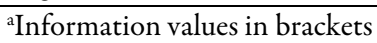

\section{Results and discussions}

\section{Major, minor and toxic trace elements}

The quality of the analytical procedure was assured using a Standard reference material (NIST-SRM 1515-Apple Leaves). The obtained values ( $\mathrm{Cd}, \mathrm{Cr}, \mathrm{Cu}, \mathrm{Fe}, \mathrm{Pb}, \mathrm{Zn}, \mathrm{Ca}, \mathrm{K}$, $\mathrm{Mg}$ and $\mathrm{Na}$ ) of CRM draw against certified values indicating that the measured values correlate well with certified values. Limits of detection (LOD) of every studied element were experimentally calculated as three times the standard deviation of ten measurements of independent reagent blank solutions. The obtained values $(\mathrm{Cd}, \mathrm{Cu}, \mathrm{Fe}, \mathrm{Mn}, \mathrm{Pb}, \mathrm{Zn}, \mathrm{Ca}$, $\mathrm{K}$ and $\mathrm{Mg}$ ) of CRM draw against certified values indicate that the measured values correlate well with certified values (Tab. 4).

Apples are considered a good source of dietary minerals. The range of concentration (mean $\pm \mathrm{SD}, \mathrm{mg} / \mathrm{kg}$ d.w.) of major and minor elements in 10 apple cultivars is given in Tabs. 5 and 6. According to the obtained results, in the edible 
Tab. 5. Mean concentration of major elements in apple samples ( $\mathrm{mg} / \mathrm{kg} \mathrm{d.w.)}$

\begin{tabular}{|c|c|c|c|c|c|c|}
\hline Sample & Year & $\mathrm{Na}$ & $\mathrm{K}$ & $\mathrm{Ca}$ & $\mathrm{Mg}$ & $\mathrm{P}$ \\
\hline \multirow{2}{*}{ 'Auriu de Cluj' } & 2012 & $9.22 \pm 1.23$ & $25660 \pm 2356$ & $286 \pm 112$ & $271 \pm 67$ & $653 \pm 111$ \\
\hline & 2013 & $7.90 \pm 1.56$ & $22530 \pm 3242$ & $190 \pm 103$ & $276 \pm 89$ & $665 \pm 102$ \\
\hline \multirow{2}{*}{ 'Florina' } & 2012 & $9.30 \pm 2.12$ & $29731 \pm 3258$ & $347 \pm 98$ & $295 \pm 78$ & $861 \pm 211$ \\
\hline & 2013 & $8.18 \pm 1.78$ & $32442 \pm 2345$ & $423 \pm 87$ & $312 \pm 65$ & $745 \pm 278$ \\
\hline \multirow{2}{*}{ 'Generos' } & 2012 & $10.9 \pm 2.12$ & $30123 \pm 3215$ & $321 \pm 110$ & $286 \pm 110$ & $521 \pm 113$ \\
\hline & 2013 & $8.58 \pm 1.78$ & $28855 \pm 3012$ & $413 \pm 102$ & $428 \pm 142$ & $730 \pm 234$ \\
\hline \multirow{2}{*}{ 'Golden Delicios' } & 2012 & $14.9 \pm 2.12$ & $41340 \pm 4012$ & $274 \pm 113$ & $284 \pm 113$ & $877 \pm 235$ \\
\hline & 2013 & $11.6 \pm 1.12$ & $40620 \pm 3121$ & $294 \pm 110$ & $345 \pm 123$ & $759 \pm 243$ \\
\hline \multirow{2}{*}{ 'Idared' } & 2012 & $10.2 \pm 2.31$ & $38630 \pm 1211$ & $356 \pm 102$ & $340 \pm 78$ & $661 \pm 213$ \\
\hline & 2013 & $8.61 \pm 1.11$ & $32030 \pm 1989$ & $330 \pm 87$ & $276 \pm 56$ & $673 \pm 214$ \\
\hline \multirow{2}{*}{ 'Jonagold' } & 2012 & $10.8 \pm 2.11$ & $32441 \pm 2312$ & $206 \pm 110$ & $266 \pm 145$ & $582 \pm 225$ \\
\hline & 2013 & $8.00 \pm 1.87$ & $31130 \pm 3211$ & $604 \pm 236$ & $467 \pm 213$ & $593 \pm 235$ \\
\hline \multirow{2}{*}{ 'Jonathan' } & 2012 & $10.3 \pm 1.45$ & $33450 \pm 1987$ & $267 \pm 87$ & $285 \pm 110$ & $666 \pm 236$ \\
\hline & 2013 & $8.63 \pm 2.01$ & $35300 \pm 2113$ & $256 \pm 98$ & $433 \pm 134$ & $678 \pm 235$ \\
\hline \multirow{2}{*}{ 'Prima' } & 2012 & $8.64 \pm 1.89$ & $21122 \pm 2345$ & $246 \pm 134$ & $285 \pm 108$ & $475 \pm 114$ \\
\hline & 2013 & $8.46 \pm 2.11$ & $28671 \pm 2345$ & $145 \pm 98$ & $401 \pm 132$ & $483 \pm 235$ \\
\hline \multirow{2}{*}{ 'Productiv de Cluj' } & 2012 & $10.3 \pm 1.11$ & $32035 \pm 2112$ & $246 \pm 45$ & $306 \pm 213$ & $533 \pm 245$ \\
\hline & 2013 & $9.93 \pm 1.23$ & $38834 \pm 3121$ & $414 \pm 87$ & $435 \pm 211$ & $543 \pm 213$ \\
\hline \multirow{2}{*}{ 'Starkrimson' } & 2012 & $9.38 \pm 1.23$ & $31126 \pm 2345$ & $267 \pm 110$ & $271 \pm 108$ & $711 \pm 325$ \\
\hline & 2013 & $8.60 \pm 2.01$ & $33440 \pm 2356$ & $359 \pm 104$ & $365 \pm 98$ & $724 \pm 112$ \\
\hline Mean values & & 9.62 & 31976 & 312 & 331 & 657 \\
\hline Standard dev. & & 1.63 & 5366 & 102 & 66.4 & 113 \\
\hline
\end{tabular}

Tab. 6. Mean concentration of minor elements in apple samples ( $\mathrm{mg} / \mathrm{kg} \mathrm{d.w.)}$

\begin{tabular}{|c|c|c|c|c|c|c|}
\hline Sample & Year & $\mathrm{Cu}$ & $\mathrm{Fe}$ & $\mathrm{Mn}$ & $\mathrm{Sr}$ & $\mathrm{Zn}$ \\
\hline \multirow{2}{*}{ 'Auriu de Cluj' } & 2012 & $4.02 \pm 1.02$ & $3.24 \pm 0.96$ & $1.69 \pm 0.59$ & $0.857 \pm 0.331$ & $1.15 \pm 0.63$ \\
\hline & 2013 & $2.34 \pm 1.12$ & $2.84 \pm 0.89$ & $1.05 \pm 0.75$ & $0.451 \pm 0.292$ & $2.12 \pm 0.56$ \\
\hline \multirow{2}{*}{ 'Florina' } & 2012 & $3.49 \pm 1.13$ & $2.55 \pm 0.45$ & $1.98 \pm 0.65$ & $0.640 \pm 0.451$ & $1.85 \pm 0.78$ \\
\hline & 2013 & $2.99 \pm 1.23$ & $3.30 \pm 0.89$ & $1.45 \pm 0.45$ & $0.384 \pm 0.112$ & $2.75 \pm 0.98$ \\
\hline \multirow{2}{*}{ 'Generos' } & 2012 & $3.54 \pm 0.98$ & $5.00 \pm 1.11$ & $1.80 \pm 0.78$ & $0.944 \pm 0.653$ & $2.20 \pm 1.12$ \\
\hline & 2013 & $2.94 \pm 0.99$ & $2.84 \pm 1.23$ & $0.70 \pm 0.72$ & $0.406 \pm 0.122$ & $1.98 \pm 0.89$ \\
\hline \multirow{2}{*}{ 'Golden Delicios' } & 2012 & $6.14 \pm 1.24$ & $5.44 \pm 0.89$ & $1.63 \pm 0.65$ & $0.856 \pm 0.234$ & $3.05 \pm 1.25$ \\
\hline & 2013 & $4.84 \pm 1.35$ & $3.05 \pm 0.67$ & $1.10 \pm 0.48$ & $0.454 \pm 0.112$ & $2.55 \pm 1.23$ \\
\hline \multirow{2}{*}{ 'Idared' } & 2012 & $2.09 \pm 0.78$ & $2.70 \pm 0.56$ & $2.89 \pm 0.96$ & $1.16 \pm 0.34$ & $1.00 \pm 0.56$ \\
\hline & 2013 & $3.94 \pm 1.12$ & $3.26 \pm 0.78$ & $1.15 \pm 0.45$ & $0.505 \pm 0.235$ & $1.88 \pm 1.01$ \\
\hline \multirow{2}{*}{ 'Jonagold' } & 2012 & $3.11 \pm 1.56$ & $3.24 \pm 1.12$ & $1.95 \pm 0.65$ & $0.665 \pm 0.112$ & $0.88 \pm 0.23$ \\
\hline & 2013 & $3.24 \pm 0.75$ & $3.81 \pm 1.10$ & $2.10 \pm 0.43$ & $0.353 \pm 0.098$ & $1.98 \pm 1.12$ \\
\hline \multirow{2}{*}{ 'Jonathan' } & 2012 & $3.24 \pm 0.68$ & $3.11 \pm 0.89$ & $1.78 \pm 0.65$ & $0.577 \pm 0.101$ & $1.05 \pm 0.89$ \\
\hline & 2013 & $4.54 \pm 1.13$ & $5.41 \pm 1.13$ & $2.25 \pm 0.78$ & $0.534 \pm 0.089$ & $2.47 \pm 1.23$ \\
\hline \multirow{2}{*}{ 'Prima' } & 2012 & $2.32 \pm 0.78$ & $4.98 \pm 0.75$ & $2.00 \pm 0.99$ & $0.748 \pm 0.231$ & $1.48 \pm 0.75$ \\
\hline & 2013 & $4.23 \pm 1.89$ & $4.92 \pm 1.14$ & $2.01 \pm 0.78$ & $0.751 \pm 0.320$ & $1.49 \pm 0.97$ \\
\hline \multirow{2}{*}{ 'Productiv de Cluj' } & 2012 & $3.12 \pm 1.12$ & $2.57 \pm 1.03$ & $1.68 \pm 0.45$ & $0.486 \pm 0.114$ & $1.47 \pm 0.56$ \\
\hline & 2013 & $5.04 \pm 1.13$ & $3.69 \pm 0.89$ & $3.20 \pm 0.59$ & $0.490 \pm 0.105$ & $2.33 \pm 1.12$ \\
\hline \multirow{2}{*}{ 'Starkrimson' } & 2012 & $2.14 \pm 0.87$ & $3.81 \pm 0.92$ & $1.94 \pm 1.00$ & $0.872 \pm 0.212$ & $2.45 \pm 0.78$ \\
\hline & 2013 & $4.12 \pm 1.14$ & $3.95 \pm 1.12$ & $1.95 \pm 0.89$ & $0.873 \pm 0.321$ & $2.42 \pm 1.25$ \\
\hline Mean values & & 3.57 & 3.68 & 1.81 & 0.65 & 1.93 \\
\hline Standard dev. & & 1.05 & 0.96 & 0.58 & 0.22 & 0.62 \\
\hline
\end{tabular}


527

part of the apple, the concentration for the major-elements varies in the following way: $\mathrm{K}>\mathrm{Ca}>\mathrm{P}>\mathrm{Mg}>\mathrm{Na}$ and $\mathrm{Fe}>$ $\mathrm{Cu}>\mathrm{Zn}>\mathrm{Mn}>\mathrm{Sr}$ for the micro-elements, respectively.

\section{Major elements}

Among the major elements examined in apple fruits, $\mathrm{K}$ was the most abundant with an overall mean concentration of $31976 \pm 5366 \mathrm{mg} / \mathrm{kg}$. This result was comparable with the data reported for apple fruits by Cindric et al. (2012) $(38600$ $\mathrm{mg} / \mathrm{kg}$ ) and higher than those determined by Hamurcu et al. (2010) - $863 \mathrm{mg} / \mathrm{kg}$, Horsley et al. (2014) - $10226 \mathrm{mg} / \mathrm{kg}$, and Ozcan et al. (2012) - $7000 \mathrm{mg} / \mathrm{kg}$. The obtained values for $\mathrm{Na}(9.62 \pm 1.63 \mathrm{mg} / \mathrm{kg})$ were similar to those reported by Cindric et al. (2012) - $9.92 \mathrm{mg} / \mathrm{kg}$, and lower than those determined by Humurcu $(37.0 \mathrm{mg} / \mathrm{kg})$ and Ozcan $(600$ $\mathrm{mg} / \mathrm{kg}$ ). Adults should consume $4700 \mathrm{mg} \mathrm{K} /$ day and 1500 mg Na/day (deMan, 1999). Apple fruits may be a good source of potassium, which plays an important role in the human body, especially in the transmission process of nerve signals, but also in fluid balance and proper function of heart, muscles, kidney and hormones. Sodium plays a key role in muscle and nerve function and work with potassium to coregulate ATP and fluids.

In both years, the highest values for $\mathrm{K}$ and $\mathrm{Na}$ were observed in 'Golden Delicious' ( $41340 \mathrm{mg} / \mathrm{kg} \mathrm{K}$ and 14.9 $\mathrm{mg} / \mathrm{kg} \mathrm{Na}-2012)$ and $(40620 \mathrm{mg} / \mathrm{kg} \mathrm{K}$ and $11.6 \mathrm{mg} / \mathrm{kg} \mathrm{Na}$ 2013), while the lowest in 'Prima' (K: $21122 \mathrm{mg} / \mathrm{kg}$; Na: 8.64 $\mathrm{mg} / \mathrm{kg}$ - 2012) and 'Auriu de Cluj' (K: $22530 \mathrm{mg} / \mathrm{kg}$ and $7.90 \mathrm{mg} / \mathrm{kg} \mathrm{Na}$ - 2013).

Calcium and magnesium also play an essential role in muscle function, nerve transmission, bone and teeth formation and hormone secretion; furthermore, magnesium is required for processing ATP. The Recommended dietary allowance, RDA (average daily dietary intake level sufficient to meet the nutrient requirements of nearly all, $97-98 \%$ healthy individuals in a particular life-stage or gender group) for adults is $1000 \mathrm{mg} \mathrm{Ca} /$ day, and $400 \mathrm{mg} \mathrm{Mg} /$ day (deMan, 1999). It should also have to be considered the role of calcium to the maintenance of fruit ripening and optimum quality during postharvest storage. This role is enhanced directly in the prevention of specific disorders (bitter pit) and in relationships between calcium and general quality properties (flesh firmness) (Ferguson and Watkins, 1982). The content of $\mathrm{Ca}(312 \pm 102 \mathrm{mg} / \mathrm{kg})$ and $\mathrm{Mg}(331 \pm 66.4 \mathrm{mg} / \mathrm{kg})$ were ten times lower than the reported results for apples (4410 $\mathrm{mg} / \mathrm{kg}-\mathrm{Ca}$ and $3140 \mathrm{mg} / \mathrm{kg}$ ) by Cindric et al. (2012).

Regarding to the annual variations, the concentration of $\mathrm{Ca}$ and $\mathrm{Mg}$ were highest in 'Idared' ( $356 \mathrm{mg} / \mathrm{kg} \mathrm{Ca}$ and 340 $\mathrm{mg} / \mathrm{kg} \mathrm{Mg}$ - 2012) and 'Jonagold' (604 mg/kg Ca and 467 $\mathrm{mg} / \mathrm{kg} \mathrm{Mg}$ - 2013), while the lowest was in 'Jonagold' (206 $\mathrm{mg} / \mathrm{kg} \mathrm{Ca}$ and $266 \mathrm{mg} / \mathrm{kg} \mathrm{Mg}$ - 2012), Prima (145 mg/kg Ca-2013), 'Auriu de Cluj' and 'Idared' (276 mg/kg Mg 2013).

Phosphorous is a very important component of the bones and cells having an important role in protein production to satisfy the needs of the human body. The RDA for daily phosphorous for adults is $700 \mathrm{mg} \mathrm{P} /$ day (deMan, 1999). The obtained values for $\mathrm{P}(657 \pm 113 \mathrm{mg} / \mathrm{kg})$ were similar to those obtained by Hamurcu et al. (2010) - $700 \mathrm{mg} / \mathrm{kg}$ and Horsley et al. (2014) - $683 \mathrm{mg} / \mathrm{kg}$. In both years, 'Golden Delicious' exhibited the highest content of $\mathrm{P}(877 \mathrm{mg} / \mathrm{kg}$ 2012 and 759 mg/kg - 2013), while 'Prima' exhibited the lowest content $(475 \mathrm{mg} / \mathrm{kg}-2012$ and $483 \mathrm{mg} / \mathrm{kg}$ - 2013).

Regarding the annual variation on minor and major element concentrations, the obtained mean concentration was similar to those from both years. 'Golden Delicious' apple had the highest average content of major elements.

One apple ( $300 \mathrm{~g}$ fresh weight or $40 \mathrm{~g}$ dry matter $)$ can offer up to $1279 \mathrm{mg} \mathrm{K}$ (27.2\% RDA), $0.38 \mathrm{mg} \mathrm{Na}(0.03 \%$ of $\mathrm{RDA}), 12.5 \mathrm{mg} \mathrm{Ca}(1.25 \%$ of RDA), $13.3 \mathrm{mg} \mathrm{Mg}$ (3.31\% of $\mathrm{RDA})$ and $26.3 \mathrm{mg} \mathrm{P}(3.75 \%$ of $\mathrm{RDA})$. As a result, major elements were found to have good nutritional contribution in accordance to RDA.

\section{Minor elements}

The minor-elements also support important functions of the human body. Iron is necessary to produce hemoglobin and myoglobin, proteins that carry oxygen in the human body. Manganese, one of the vital important elements, enhances the absorption of calcium and plays an important role in the production of bones and connective tissues. Chromium enhances the action of insulin, making it important in blood sugar regulation processes. The human body needs copper and zinc as well, to produce enzymes involved in protection against oxidative processes. Strontium can improve the cellular make-up of bones and teeth by preventing tooth decay of soft bones (WHO, 2006; Vicente et al., 2014).

In both years, the concentrations of investigated minor elements in all apple samples were: $\mathrm{Cu}(3.57 \mathrm{mg} / \mathrm{kg}), \mathrm{Fe}(3.68$ $\mathrm{mg} / \mathrm{kg}), \mathrm{Mn}(1.81 \mathrm{mg} / \mathrm{kg}), \mathrm{Sr}(0.65 \mathrm{mg} / \mathrm{kg})$ and $\mathrm{Zn}(1.93$ $\mathrm{mg} / \mathrm{kg}$ ). According to RDA of investigated minor elements $(\mathrm{Cu}-1.2 \mathrm{mg} /$ day, $\mathrm{Fe}-8.0 \mathrm{mg} /$ day, $\mathrm{Mn}-2.3 \mathrm{mg} /$ day, $\mathrm{Sr}-$ not stated, Zn - $11.0 \mathrm{mg} /$ day; deMan, 1999), one apple can provide $0.143 \mathrm{mg} \mathrm{Cu}$ (11.9\% of RDA), $0.147 \mathrm{mg} \mathrm{Fe}(1.84 \%$ of RDA), $0.073 \mathrm{mg} \mathrm{Mn} \mathrm{(3.16 \%} \mathrm{of} \mathrm{RDA)} \mathrm{and} 0.077 \mathrm{mg} \mathrm{Zn}$ ( $0.70 \%$ of RDA).

\section{Toxic trace elements}

In all samples, the contents of heavy metals $(\mathrm{Cd}, \mathrm{Cr}$ and $\mathrm{Pb})$ were below the limit of detection (0.01, 0.10 and 0.01 $\mathrm{mg} / \mathrm{kg}$, respectively). European legislation (1881/2006/EC setting maximum levels for certain contaminants in foodstuffs) regulates the maximum admitted concentration of $\mathrm{Pb}(0.10 \mathrm{mg} / \mathrm{kg}$ wet weight $)$ and $\mathrm{Cd}(0.05 \mathrm{mg} / \mathrm{kg}$ wet weight) in fruits. The obtained concentrations of $\mathrm{Pb}$ and $\mathrm{Cd}$

Tab. 7. Concentrations (mg/100g d.w.) of catechin, epicatechin and quercetin, determined in different cultivars of apple fruits

\begin{tabular}{cccc}
\hline \multirow{2}{*}{ Cultivar } & \multicolumn{3}{c}{ Concentration $(\mathrm{mg} / 100 \mathrm{~g}$ d.w.) } \\
\cline { 2 - 4 } & Catechin & Epicatechin & Quercetin \\
\hline 'Auriu de Cluj' & 0.55 & 6.02 & 9.53 \\
\hline 'Florina' & 0.58 & 6.42 & 12.21 \\
\hline 'Generos' & 0.68 & 5.93 & 10.44 \\
'Golden Delicios' & 0.62 & 6.03 & 10.02 \\
\hline 'Idared' & 0.83 & 7.83 & 12.69 \\
'Jonagold' & 1.04 & 9.87 & 14.33 \\
'Jonathan' & 0.71 & 5.88 & 10.69 \\
\hline 'Prima' & 0.49 & 5.65 & 9.84 \\
'Productiv de Cluj' & 0.44 & 6.21 & 8.99 \\
\hline 'Starkrimson' & 0.52 & 5.81 & 10.25 \\
\hline
\end{tabular}


in all apple samples were lower than the values set by European legislation, indicating no harmful impact on human health by the consumption of the apples grown in this part of Romania.

\section{Polyphenols content}

Three apple polyphenols, namely catechin, epicatechin and quercetin, were determined (Tab. 7). The concentrations of polyphenols were slightly different among cultivars, with some increases for 'Idared' and 'Jonathan'. Several other studies confirmed earlier that the content of polyphenols differs by variety and is affected by different factors such as: apple variety, fruit development, conditions during long-term storage, superficial scald development in apple fruit and solar radiation (Lachman et al., 2006). Taking into consideration the fact that the investigated cultivars were selected from the same orchard, were grown under similar conditions and were sampled of their positions, it can be concluded that the differences in polyphenols quantity depends only on the apple variety.

In all investigated apple cultivars, quercetin was proved to be the major polyphenol, with concentrations from 8.99 to $12.21 \mathrm{mg} / 100 \mathrm{~g}$ d.w. The concentrations decreased to epicatechin (from 5.88 to $9.87 \mathrm{mg} / 100 \mathrm{~g} \mathrm{d.w}$ ) and to catechin (from 0.49 to $1.04 \mathrm{mg} / 100 \mathrm{~g} \mathrm{~d} . \mathrm{w}$ ). Similar results were obtained in other studies (Manach et al., 2005).

A recent study (Randall, 2012) suggest that the daily dose of $300 \mathrm{mg}$ to $600 \mathrm{mg}$ of apple polyphenols may be all that is needed to obtain good health benefits. The present results suggest that catechin, epicatechin and quercetin from $100 \mathrm{~g}$ dried apples cover only $0.666 \%$ from the necessary dose. Manach et al. (2005) support the idea that the most abundant polyphenols in our diet, are not necessarily leading to the highest concentration of active metabolites in target tissues, the three investigated polyphenols being of great interest for our health.

\section{Conclusion}

The results of this study provide valuable data regarding major-to-trace elements and polyphenols in different apple cultivars, under climate conditions of Cluj-Napoca area, Romania. The investigated apple samples contain significant amounts of several essential elements and polyphenolic compunds as well. Apple consumption represents a valuable and a very important source of minerals and antioxidants. Toxic element concentrations $(\mathrm{Cd}, \mathrm{Cr}$ and $\mathrm{Pb})$ were below the limits of detection showing no harmful effects caused by these elements through the high consumption of apples. Regarding the annual variation on minor and major element concentrations, the obtained mean concentration were similar in both years. The LC/MS/MS method was proved to be a robust and useful technique for polyphenols' determination. The results obtained are of interest especially for the medical world due to the aminoacid characteristics of the investigated polyphenols. These data should prove useful especially for the medical world when designing anti-cancer, antiangiogenic, anti-mutagenic, hypocholesterolemic, antiageing, anti-diabetic, anti-bacterial, anti-HIV and antiinflammatory treatments.

\section{Acknowledgments}

This research was supported by the Executive Unit for Financing Higher Education, Research, Development and Innovation (UEFISCDI), Capacities, Bilateral cooperation Programme Romania-Austria, project number 546/2012.

\section{References}

Auclair S, Silberberg M, Gueux E, Morand C, Mazur A, Milenkovic D (2008). Apple polyphenols and fibers attenuate atherosclerosis in apolipoprotein E-deficient mice. J Agric Food Chem 56(14):5558-5563.

Barnes KW (1999). The Nutritional Analysis of Fruit Juices. PerkinElmer, ICP Optical Emission Application Note.

Bocca B, Conti ME, Pino A, Mattei D, Forte G, Alimonti A (2007). Simple, fast, and low-contamination microwaveassisted digestion procedures for the determination of chemical elements in biological and environmental matrices by sector field ICP-MS. Int J Environ Anal Chem 87(15):11111123.

Chang CL, Wu RT (2011). Quantification of (+)-catechin and (-)-epicatechin in coconut water by LC-MS. Food Chem 126:710-717.

Cindric J, Krizman I, Zeimer M, Kampic S, Medunic G. Stingeder G (2012). ICP-AES determination of minor- and major elements in apples after microwave assisted digestion. Food Chem 135(4):2675-2680.

Davidowski L, Grosser Z, Sarojam P (2009). The analysis of baby foods and juices for metals to protect a sensitive population. Perkin Elmer Application Note.

deMan JM (1999). The principles of food chemistry (3rd ed.). Gaithersburg: Aspen Publishers.

Enomoto T, Nagasako-Akazome Y, Kanda T, Ikeda M, Dake Y (2006). Clinical Effects of Apple Polyphenols on Persistent Allergic Rhinitis: A Randomized Double-Blind PlaceboControlled Parallel Arm Study. J Allerg Clin Immunol 16(5):283-289.

Escudero MR, Escudero DFR, Remsberg CM, Takemoto JK, Davies NM, Yanez JA (2008). Identification of Polyphenols and Anti-Oxidant Capacity of Piper aduncum L. Open Bioact Compd J 1:18-21.

Ferguson IB, Watkins CB (1982). The interaction of copper and zinc with calcium in apple fruit. Sci Hortic 17:319-325.

Froes RES, Neto WB, Naveira RLP, Silva NC, Nascentes CC, da Silva JBB, (2009). Multivariate optimization by exploratory analysis applied to the determination of microelements in fruit juice by inductively coupled plasma optical emission spectrometry. Spectrochim Acta Part B 64:619-622.

Hamurcu M, Ozcan MM, Dursun N, Gezgin S (2010). Mineral and heavy metal levels of some fruits grown at the roadsides. Food Chem Toxicol 48:1767-1770.

Horsley R, Gökbel H, Özcan MM, Harmankaya M, Şimşek S (2014). Monitoring of Element Contents of Three Different 
Apple (Malus Spp.) Varieties in an Apple Tree. Journal of Food and Nutrition Research 2(3):127-129.

Hossain MB, Rai DK, Brunton NP, Martin-Diana AB, BarryRyan C (2010). Characterization of phenolic composition in Lamiaceae spices by LC-ESI-MS/MS. J Agr Food Chem 58(19):10576-10581.

Hyson DA (2011). A comprehensive review of apples and apple components and their relationship to human health. Adv Nutr 2:408-420.

Ko SH, Choi SW, Ye SK, Cho BL, Kim HS, Chung MH (2005). Comparison of the antioxidant activities of nine different f1 ruits in human plasma. J Med Food 8(1):41-46.

Krushevska A, Barnes RM, Amarasiriwaradena C (1993) Decomposition of biological samples for inductively coupled plasma atomic emission spectrometry using an open focused microwave digestion system. Analyst 118:1175-1178.

Lachman J, Sulc M, Sus J, Pavlikova O (2006). Polyphenol content and antiradical activity in different apple varieties. Hort Sci (Prague) 33:95-102.

Lamble KJ, Hill SJ (1998). Microwave digestion procedures for environmental matrices. Analyst 123: 103R-133R.

Manach C, Williamson G, Morand C, Scalbert A, Remesy C (2005). Bioavailability and bioefficacy of polyphenols in humans. I. Review of 97 bioavailability studies. Am J Clin Nutr 81(1 Suppl):230S-242S.

Militaru M, Braniste N, Butac M, Sestras A, Sotiropoulos T, Lukić M, Ambrozič Turk B, Dzhuvinov V (2013). Review of pome fruit breeding in Balkan. Acta Hort 981:177-184.

Ozcan MM, Harmankaya M, Gezgin S (2012). Mineral and heavy metal contents of the outer and inner tissues of commonly used fruits. Environ Monit Assess 184:313-320.

Pandey KB, Rizvi SI (2009). Plant polyphenols as dietary antioxidants in human health and disease. Oxid Med Cell Longev 2 (5):270-278.
Randall G (2012). Apple Polyphenols and Longevity, http://www.lef.org/en/Magazine/2012/4/ApplePolyphenols-Longevity/Page-02/.

Sestras R, Oprea S, Barbos A, Sestras A, Dejeu M (2006). Recent advances in apple breeding at Cluj-Napoca, Romania. Bulletin of the University of Agricultural Sciences and Veterinary Medicine. Horticulture Series 63:405.

Vieira FGK, Borges GDC, Copetti C, Amboni RDDMC, Denardi F, Fett R (2009). Physico-chemical and antioxidant properties of six apple cultivars (Malus domestica Borkh) grown in southern Brazil. Sci Hortic 122:421-425.

Vicente AR, Manganaris GA, Ortiz CM, Sozzi GO, Crisosto CH (2014). Nutritional Quality of Fruit and Vegetables, p. 57106. Chapter 5. In: Florkowski, Shewfeit, Brueckner and Prussia (eds.) Postharvest Handling: A Systems Approach, Second Edition. Oxford: Academic Press, Elsevier.

Wang L, Morris ME (2005). Liquid chromatography-tandem mass spectroscopy assay for quercetin and conjugated quercetin metabolites in human plasma and urine. J Chromatogr B, 821:194-201.

Weingerl V, Strlic M, Kocar D (2009). Comparison of methods for determination of polyphenols in wine by HPLC-UV/VIS, LC/MS/MS and Spectrophotometry. Acta Chim Slov 56:698-703.

World Health Organization (WHO) (2006). Evaluation of Certain Food Additives and Contaminants. Geneva, Switzerland, WHO Technical Report Series 930.

Wu J, Gao H, Zhao Liao X, Chen F, Wang Z, Xiaosong H (2007). Chemical compositional characterization of some apple cultivars. Food Chem 103(1):88-93.

Zeiner M, Juranovic Cindric I, Kroppl M, Stingeder G (2010). Determination of copper in clarified apple juices. J Agric Food Chem 58:3617-3620.

*** Food and Agriculture Organization of the United Nations (FAO) (2011). http://faostat3.fao.org. 